na Workshop, Da Nang, Vietnam 4-7, March 1996. pp 119-123.

Jacobs, M. (1988): The Tropical Rain Forest. Springer, Berlin. 295 pp.

Hoffmann, C. C. (2002): Pollen distribution in sub-recent sedimentary environments of the Orinco Delta (Venezuela)- an Actuo-Paleobotanical study. Review of Paleobotany and Palynology 119: 191-217.

ISTA (1993): International rules for seed testing. Supplement rules. Seed Science and Technology 21: 157.

KIMONDO, J. M. (1996): Two-year growth performance of Casuarina equisetifolia provenances in Gede, Kenya. In: Proc. Recent Casuarina research and Development. K. Pinyopusarerk, J. W. Turnbull and S. J. Midgley (Eds.). Third International Casuarina workshop, Da Nang, Vietnam 4-7, March 1996. pp. 124-130.

Little, E. L., R. O. Woodbury and F. H. Woodsworth (1974): Trees of Puerto Rico and the Virgin Island, Vol.2 Department of Agriculture, Washington, DC, 1024 pp.

LlOYD, D. J. and C. J. WeBB (1977).: Secondary sex characters in seed plants. Bot. Rev. 43: 177-216

Longman, K. A. and J. JenIK (1987): Tropical Rain Forest and its environment Wiley, New York, $325 \mathrm{pp}$.

MaAs, P. J. M. and L. Y. TH. WeEstRA (1993): Neotropical Plant families. Koetz Scientific Books, Konigstein 289 pp.

MabBerley, D. J. (1992): Tropical Rain Forest Ecology. Blackie, London, 300 pp.

Mahadevan, N. P., K. Shanthi and B. G. Singh (1994): Sexual system in Casuarina equisetifolia. Sylva Plus, IFGTB Newsletter (Biodiversity special) 2: 17.

Martin, F. W. (1959): Staining and observing pollen tubes in the style by means of fluorescence. Stain Technol. 34: 125-128.

NagARajan, B., A. Nicodemus, A. K. Mandal, R. K. Verma and N. P. MAHADEVAN (1998): Phenology and controlled pollination studies in tamarind. Silvae Genet. 47(5-6): 237-241.

Nagarajan, B., A. Nicodemus, M. Varghese and V. SIVAKUMAR (2001): Reproductive Biology of Casuarina equisetifolia. In: Casuarina: Improvement and Utilisation Eds: K. Gurumurthy, A. Nicodemus and SidAPPA (Eds.) Institute of Forest Genetics and Tree Breeding, India ISBN 81-900346, Pp: 63-68.
Nicodemus, A., M. VARGHese and B. NAGARAJAN (2001): Genetic improvement of Casuarina equisetifolia through selection and breeding. In: GuRUMURTHI, K., Nicodemus, A. and SidDAPPA (Eds.) Casuarina in India: Improvement and Utilization. Institute of Forest Genetics and Tree Breeding, Coimbatore, India. pp 3-13.

PALUPI, E. R. and J. OwENS (1998): Reproductive phenology and reproductive success of teak (Tectona grandis L.f.). Int. J. Plant Sci. 159(5): 833-842.

Pinyopusarerk, K., E. R. Williams, V. LuANGVIRIYASAENG and B. PURIYAKORN (1996): Geographic variation in growth and morphological traits of Casuarina equisetifolia. In: K. PinYopusarerk, J. W. TURnBull and S. J. Midgley (Eds.). Recent Casuarina Research and Development. Proc. of the third International Casuarina Workshop Da Nang, Vietnam 4-7, March 1996. pp 143-151.

RADFord, A. E., W. C. Dickinson, J. R. Massey and C. R. BELL (1974): Vascular plant systematics. Harper and Row Publishers, New York, USA.

Stock, J., M. VAGAs, K. AnAGARITA and R. GonzAlez (2004): Seed production in Gmelina arborea by controlled pollination. New Forests 28: 167-177.

Sharma, N., A. K. Koul and V. Kaul (1999): Pattern of resource allocation of six Plantago species with different breeding systems. Jour. Plant Res. 112: 1-5.

VARghese, M., D. Lindgren and A. Nicodemus (2004): Fertility and Effective population size in Seedling Seed Orchards of Casuarina equisetifolia and C. junghuhniana. Silvae Genetica 53: 164-168.

VeERENDRA, H. C. S. and H. S. AnANDTAPAdmanaba (1996): The breeding system in Sandal (Santalum album L.). Silvae Genet. 45 (4): 188-190.

Whitmore, T. C. (1992): An Introduction to Tropical Rain Forests, Clarendon, Oxford, $226 \mathrm{pp}$.

YANG, J. C. and T. H. Chen (1996): Provenance trial of Casuarina equisetifolia in Taiwan. II. Performance in two years. In: K. PinYopusRerk, J. W. TURnBUlL and S. J. Midgley (Eds). Recent Casuarina Research and Development. Proc. of the Third International Casuarina Workshop Da Nang, Vietnam 4-7 March 1996. pp 152-158.

\title{
Segregation and Linkage Relationships of Allozymes in Pinus Brutia Ten.
}

\author{
By N. KAYA ${ }^{1)}$ and K. IsIK \\ Akdeniz University, Faculty of Arts and Sciences, Department of Biology, 07058 Antalya, Turkey
}

(Received $21^{\text {th }}$ October 2005)

\begin{abstract}
Female gametophytes of Pinus brutia Ten. were analyzed to study Mendelian segregation and linkage among allozyme loci in a seed orchard composed of 28

\footnotetext{
1) Corresponding author: NURAY KAYA, Phone: +(90)-242-3102366;
}

Fax: + (90)-242-2278911; e-mail: nkaya@akdeniz.edu.tr
\end{abstract}

clones. Isozyme variants of nine enzyme systems encoding 14 loci from megagametophytes were assayed by starch gel electrophoresis. While six of the 14 loci were monomorphic, the remaining eight were polymorphic. Analysis of observed segregation ratios of all polymorphic loci except for $S d h 1$, showed a good fit to the 1:1 ratios expected for Mendelian inheritance. Linkage rela- 
tionships of the eight polymorphic allozyme loci were analyzed by testing 23 of the 28 possible two-locus combinations. Two-locus segregations in three pairs (Got2Mdh1, Got2-Pgi2 and Pgd3-Sdh1) were significantly heterogeneous $(\mathrm{P} \leq 0.05)$. Relatively weak linkage was observed between only one pair of genes (Adh2:Got2). Recombination fraction for Adh2:Got2 was found to be $0.24( \pm 0.06)$.

Key words: linkage, allozyme, inheritance, seed orchard, Pinus brutia.

\section{Introduction}

Allozyme analyses are used in a wide area of forest genetics: genome mapping, mating system analysis, genetic variation and diversity studies, taxonomic determinations, and forest tree improvement programs (BRown et al., 1975; NEALE and ADAMs, 1981; BoYLE and Morgenstern, 1985; Strauss and ConkLe, 1986; Niebling et al., 1987; Szmidt and Muona, 1989). Segregation distortion of allozymes can affect the evolution of natural populations and can cause biased estimates of allele frequencies, heterozygosities and mating system parameters (CHELIAK et al., 1984; STRAUSs and CONKLE, 1986). Therefore, the study of segregation distortion provides important information for use in population genetic studies. Furthermore, many studies in forest genetics require information from unlinked loci, especially those that include the interpretation of multilocus genetic structure (STRAUSS and CONKLE, 1986). In addition, information from the linkage of loci coding for quantitative characters can be a powerful tool in plant breeding (FAROOQ and AZAM, 2002).

In gymnosperms, linkage is easily analyzed by using the female gametophyte. When studying maternal gametes, crosses are not needed because of the haploid nature of this tissue, and their easily interpreted allozyme phenotypes (CHELIAK and Pitel, 1985; StraUss and CONKLE, 1986).

To our knowledge, no linkage information for $P$. brutia isozyme variants has been published to date. The main objectives of this study were to examine segregation distortion and to investigate the occurrence of linkage among allozyme loci of $P$. brutia.

\section{Material and Methods}

The genotypes of 28 P. brutia clones from a seed orchard were determined at 14 allozyme loci by KAYA et al. (2005). Eight of the 14 loci studied were polymorphic among the 28 clones. In the current study, to determine segregation and linkage relationship of allozyme loci in $P$. brutia, we obtained seeds from 25 of these genetically identified 28 clones, because these 25 clones were heterozygous at two or more of the eight polymorphic loci (KAYA et al., 2005). Megagametophytes of about 45 to 50 wind pollinated seeds were analyzed, using starch gel electrophoresis for each heterozygous locus in each of 25 clones. Analyses were performed on eight polymorphic loci: Adh2, Got2, Mdh1, Mnr2, Pgd2, Pgd3, Pgi2 and $S d h 1$. The enzymes are listed in Table 1 along with their enzyme commission numbers, abbreviations, gel buffers used, and numbers of loci scored. Details for electrophoresis procedures, including band pattern interpretation, have been presented in previous studies (KARA et al., 1997; KAYA, 2001; KAYA et al., 2005).

In order to determine segregation distortion, the 1:1 ratio of variants in each polymorphic locus was tested for each segregating pair of allozymes by a Chi-square goodness-of-fit test. To find linkage relationships, 23 of the possible 28 two-locus combinations were found among the 25 clones sampled. Chi-square tests for linkage were performed following the procedure described in ADAMS and JOLLY (1980) for all segregating pairs of loci.

Table 1. - The assayed enzymes, their abbreviations, enzyme commission numbers, gel buffers used, and numbers of loci scored in Pinus brutia.

\begin{tabular}{|l|l|l|l|c|}
\hline Enzyme's name & Abbreviation & E.C. No. & Buffer* & $\begin{array}{c}\text { Numbers of loci } \\
\text { scored }\end{array}$ \\
\hline Aconitase & Aco & 4.2 .1 .3 & $\mathrm{MC}_{6.1}$ & 1 \\
\hline Alcohol dehydrogenase & Adh & 1.1 .1 .1 & $\mathrm{TBE}$ & 1 \\
\hline Glutamate dehydrogenase & Gdh & 1.4 .1 .2 & $\mathrm{TC}$ & 1 \\
\hline Glutamate oxaloacetate-transaminase & Got & 2.6 .1 .1 & $\mathrm{TC}$ & 3 \\
\hline Malate dehydrogenase & Mdh & 1.1 .1 .37 & $\mathrm{MC}_{8.1}$ & 1 \\
\hline Menadione reductase & $\mathrm{Mnr}$ & 1.6 .99 .2 & $\mathrm{TBE}$ & 2 \\
\hline 6-Phosphogluconate dehydrogenase & $6 \mathrm{pgd}$ & 1.1 .1 .44 & $\mathrm{MC}_{6.1}$ & 2 \\
\hline Phosphoglucoisomerase & Pgi & 5.3 .1 .9 & $\mathrm{MC}_{8.1}$ & 1 \\
\hline Shikimate dehydrogenase & Sdh & 1.1 .1 .25 & $\mathrm{MC}_{6.1}$ & 2 \\
\hline
\end{tabular}

$* \mathrm{MC}_{6.1}=$ Morpholine Citrate $\left(\mathrm{pH}\right.$ 6.1); $\mathrm{MC}_{8.1}=$ Morpholine Citrate ( $\mathrm{pH}$ 8.1); TBE = Tris-Borate-EDTA; $\mathrm{TC}=$ Tris-Citrate. Details on the gel buffers are reported in KARA et al., 1997 . 
Table 2. - Observed single locus segregation of allozymes from heterozygous mother trees. Chi-square tests of heterogeneity of mother trees and goodness of fit to the 1:1 ratio.

\begin{tabular}{ccccccccc}
\hline & \multicolumn{3}{c}{ Alleles } & \multicolumn{9}{c}{ Heterogeneity } & \multicolumn{2}{c}{ Segregation } \\
\cline { 2 - 9 } Locus & $\mathbf{1}$ & $\mathbf{2}$ & $\mathbf{3}$ & Total & $\chi^{\mathbf{2}}$ (df) & $\boldsymbol{P}$ & $\chi^{\mathbf{2}}$ (df=1) & $\boldsymbol{P}$ \\
\hline Adh2 & 26 & 24 & - & 50 & - & - & 0.10 & 0.780 \\
Got2 & 365 & 344 & - & 710 & $16.0(15)$ & 0.37 & 0.60 & 0.430 \\
Mdh1 & 274 & 271 & - & 546 & $21.0(10)$ & 0.02 & 0.02 & 0.900 \\
Mnrl & 120 & 147 & - & 267 & $0.80(5)$ & 0.98 & 2.70 & 0.100 \\
Pgd2 & 210 & 216 & - & 426 & $12.0(9)$ & 0.22 & 0.10 & 0.770 \\
Pgd2 & 20 & - & 14 & 34 & - & - & 1.10 & 0.300 \\
Pgd3 & 109 & 125 & - & 234 & $1.20(4)$ & 0.88 & 1.10 & 0.300 \\
Pgd3 & - & 57 & 57 & 114 & $2.60(2)$ & 0.28 & 0.00 & 1.000 \\
Pgd3 & 143 & - & 143 & 286 & $11.0(5)$ & 0.04 & 0.00 & 1.000 \\
Pgi2 & 263 & 272 & - & 536 & $19.0(12)$ & 0.09 & 0.20 & 0.700 \\
Sdh1 & $\mathbf{2 1 0}$ & $\mathbf{1 7 1}$ & - & $\mathbf{3 8 1}$ & $\mathbf{6 . 8 0}(\mathbf{8})$ & $\mathbf{0 . 5 6}$ & $\mathbf{3 . 9 9}$ & $\mathbf{0 . 0 4 6}$ \\
Sdh1 & - & 117 & 99 & 216 & $5.50(4)$ & 0.24 & 1.50 & 0.220 \\
Sdh1 & 43 & - & 46 & 89 & $0.30(1)$ & 0.61 & 0.10 & 0.750 \\
\hline
\end{tabular}

The recombination fraction ( $r$ ) was calculated by the binomial estimator: $r=\frac{k}{n}$, where $k$ is the number of observations in the smaller class (repulsion) and $n$ is the total number of observations. The standard error of $r$ is given by $\sqrt{r(1-r) / n}$ (RUDIN and EKBERG, 1978). Recombination fractions $(r)$ and their standard errors were estimated for all locus pairs.

\section{Results and Discussion}

In two previous studies (KAYA, 2001; KAYA et al., 2005), we found that 25 out of 28 orchard clones were heterozygous at two or more loci. In the current study we used these heterozygous clones for segregation and linkage analysis.

\section{Segregation Analysis}

To test the hypothesis of inheritance, Chi-square tests were calculated to determine the "goodness of fit" of segregating allozymes to the expected 1:1 ratio for megagametophytes from 25 heterozygous mother trees. Singlelocus segregation data are presented in Table 2. No locus (except for $S d h 1$ ) shows deviation at the 0.05 significance level from the 1:1 Mendelian segregation of allozymes when the data for all heterozygous trees were pooled. Deviation from the expected 1:1 ratio in megagametophytes of heterozygous mother trees has been reported for several allozyme loci in several forest tree species such as Pinus sylvestris, Pinus taeda, Picea abies and Pinus attenuata (RUDIN and EKBERG, 1978; ADAMS and Joly, 1980; NeAle and AdAMs, 1981; Strauss and Conkle, 1986). Yet, segregation distortion was not reported for the $S d h$ locus in any Pinus species. However, in black spruce (Picea mariana), Boyle and MoRGENSTERN (1985) reported significant deviations at the $S d h$ locus and suggested that this locus should not be included in further analyses of black spruce populations sampled.

Several factors could contribute to segregation distortions. These factors include (1) tendency to score the common allele most often on gels that resolve poorly, (2) distortion genes linked to isozyme loci; linkage of embryonic lethal genes, (3) differential viability of gametes carrying different alleles (differential selection) or (4) chance sampling (FURNIER et al., 1986; STRAUSS and Conkle, 1986; Geburek and Wuehlisch, 1989). It is likely that the observed segregation distortion for the Sdh1 locus in this study is due to chance sampling alone, since the trees that showed segregation distortion are the ones involving only "genotype" $1 / 2$ for this locus (Table 2). Furthermore, only one out of nine heterozygous mother trees for the Sdh1 locus deviated from the expected 1:1 mendelian segregation ratio.

Analyses of 25 clones for each of eight loci revealed significant segregation distortion only in seven cases among only six clones (Table 3 ). That is, only one clone (Clone 12) had significant distortion at more than one locus (at $P g d 3$ and $S d h 1$ ). In four cases, the common (high frequency) alleles among the 28 clones surveyed were in excess (overrepresented). In the three remaining cases, segregation distortion was in favor of low frequency (uncommon) alleles (Mdh1, Pgd3 and Pgi2). STrauss and CONKLE (1986) and ADAMS et al. (1990) indicated that overrepresentation of common alleles may, in part, explain their high frequency in populations. ADAMs et al.

Table 3. - Segregation data for clones with significant segregation distortion $(P \leq 0.05)$.

\begin{tabular}{cccc}
\hline \hline Locus & Clone & Ratio* & Excess** \\
\hline Got2 & 24 & $33: 18$ & 0.147 \\
Mdh1 & 22 & $31: 16$ & 0.160 \\
MdhI & 27 & $15: 34$ & -0.194 \\
Pgd3 & 12 & $20: 35$ & -0.136 \\
Pgi2 & 11 & $32: 17$ & 0.153 \\
Pgi2 & 15 & $6: 19$ & -0.260 \\
Sdh1 & 12 & $32: 18$ & 0.140 \\
\hline \hline
\end{tabular}

* Ratio is common allele: uncommon allele.

${ }^{* *}$ Excess = observed-expected frequency of the common allele. 
Table 4. - Two-locus segregation patterns and Chi-square test results for linkage analysis.

\begin{tabular}{|c|c|c|c|c|c|c|c|c|c|c|c|c|c|}
\hline \multirow{2}{*}{$\begin{array}{l}\text { Locus pair } \\
\text { Locus1-Locus2 }\end{array}$} & \multicolumn{4}{|c|}{ Allelic combination } & \multicolumn{2}{|c|}{ Heterogeneity $^{\#}$} & \multicolumn{2}{|c|}{$\begin{array}{c}\text { Segregation at } \\
\text { locus } 1\end{array}$} & \multicolumn{2}{|c|}{$\begin{array}{c}\text { Segregation at } \\
\text { locus } 2\end{array}$} & \multicolumn{2}{|c|}{$\begin{array}{c}\text { Joint } \\
\text { segregation }\end{array}$} & \multirow{2}{*}{$\begin{array}{l}\text { Recombination } \\
\text { Fractions (Se) }\end{array}$} \\
\hline & 11 & 12 & 21 & 22 & $\chi^{2}(\mathbf{d f})^{*}$ & $\mathbf{P}$ & $\left.\chi^{2} \mathrm{df}=1\right)$ & $\mathbf{P}$ & $\chi^{2}(\mathbf{d f}=1)$ & $\mathbf{P}$ & $\chi^{2}(\mathrm{df}=1)$ & $\mathbf{P}$ & \\
\hline Adh2-Got2 & 19 & 7 & 5 & 19 & - & - & 0.08 & 0.78 & 0.08 & 0.78 & 13.52 & $<0.01$ & $0.24(0.06)$ \\
\hline Adh2-Pgd3 & 11 & 15 & 13 & 11 & - & - & 0.08 & 0.78 & 0.08 & 0.78 & 0.72 & 0.40 & $0.44(0.07)$ \\
\hline Adh2-Pgiz & 14 & 4 & 9 & 7 & - & - & 0.12 & 0.74 & 4.24 & 0.04 & 1.88 & 0.17 & $0.38(0.08)$ \\
\hline Got2-MdhI & 80 & 75 & 78 & 67 & 29.18 (15) & 0.02 & 0.33 & 0.56 & 0.85 & 0.36 & 0.12 & 0.73 & $0.49(0.07)$ \\
\hline Got2-Mnr2 & 31 & 29 & 25 & 34 & $4.18(6)$ & 0.65 & 0.01 & 0.93 & 0.41 & 0.52 & 1.02 & 0.31 & $0.45(0.10)$ \\
\hline Got $2-P g d 2$ & 58 & 62 & 55 & 51 & $15.71(15)$ & 0.40 & 0.87 & 0.35 & 0.00 & 1.00 & 0.28 & 0.59 & $0.48(0.08)$ \\
\hline Got2-Pgi2 & 74 & 75 & 70 & 74 & $32.3(18)$ & 0.02 & 0.09 & 0.77 & 0.09 & 0.77 & 0.03 & 0.86 & $0.49(0.07)$ \\
\hline Got2-SdhI & 104 & 81 & 92 & 81 & $19.3(21)$ & 0.56 & 0.40 & 0.53 & 3.23 & 0.07 & 0.40 & 0.53 & $0.48(0.07)$ \\
\hline Mdh1-Mnr2 & 27 & 26 & 22 & 25 & $1.64(3)$ & 0.65 & 0.36 & 0.55 & 0.04 & 0.84 & 0.16 & 0.69 & $0.48(0.07)$ \\
\hline Mdhl-Pgd2 & 40 & 50 & 45 & 57 & $11.88(9)$ & 0.22 & 0.75 & 0.39 & 2.52 & 0.11 & 0.02 & 0.89 & $0.49(0.07)$ \\
\hline Mdhl-Pgd3 & 53 & 55 & 66 & 67 & $14.52(12)$ & 0.27 & 2.59 & 0.27 & 0.04 & 0.85 & $>0.01$ & 0.95 & $0.50(0.07)$ \\
\hline Mdh1-Pgi2 & 86 & 83 & 75 & 80 & $17.09(18)$ & 0.52 & 0.61 & 0.44 & 0.01 & 0.91 & 0.20 & 0.66 & $0.49(0.07)$ \\
\hline MdhI-SdhI & 77 & 76 & 69 & 52 & $7.62(15)$ & 0.93 & 3.74 & 0.05 & 1.18 & 0.28 & 0.93 & 0.33 & $0.47(0.07)$ \\
\hline Mnr2-Pgd2 & 27 & 28 & 33 & 34 & $3.86(6)$ & 0.70 & 1.18 & 0.28 & 0.03 & 0.86 & 0.00 & 1.00 & $0.50(0.07)$ \\
\hline Mnr2-Pgd3 & 27 & 27 & 29 & 47 & $7.38(6)$ & 0.29 & 3.72 & 0.05 & 2.49 & 0.11 & 2.49 & 0.11 & $0.43(0.07)$ \\
\hline Mnr2-Pgi2 & 13 & 21 & 12 & 26 & 3.08 (3) & 0.38 & 0.22 & 0.64 & 6.72 & 0.01 & 0.50 & 0.48 & $0.46(0.07)$ \\
\hline Mnr2-Sdh1 & 35 & 23 & 35 & 27 & $3.97(6)$ & 0.68 & 0.13 & 0.72 & 3.33 & 0.07 & 0.13 & 0.72 & $0.48(0.08)$ \\
\hline Pgd2-Pgd3 & 40 & 56 & 42 & 61 & $12.01(9)$ & 0.21 & 0.25 & 0.62 & 6.16 & 0.01 & 0.05 & 0.83 & $0.49(0.07)$ \\
\hline Pgd2-Pgi2 & 24 & 22 & 26 & 23 & $3.92(3)$ & 0.27 & 0.10 & 0.76 & 0.26 & 0.61 & 0.01 & 0.92 & $0.50(0.07)$ \\
\hline Pgd2-Sdh1 & 56 & 41 & 56 & 51 & $15.95(12)$ & 0.19 & 0.49 & 0.48 & 1.96 & 0.16 & 0.49 & 0.48 & $0.48(0.08)$ \\
\hline Pgd3-Pgi2 & 60 & 65 & 67 & 64 & $12.51(15)$ & 0.64 & 0.14 & 0.71 & 0.02 & 0.90 & 0.25 & 0.62 & $0.48(0.09)$ \\
\hline Pgd3-SdhI & 77 & 43 & 78 & 66 & 28.00 (15) & 0.02 & 2.18 & 0.14 & 8.02 & 0.01 & 1.83 & 0.18 & $0.46(0.07)$ \\
\hline Pgiz-SdhI & 62 & 73 & 81 & 57 & $17.68(18)$ & 0.48 & 0.03 & 0.85 & 0.62 & 0.43 & 4.5 & 0.03 & $0.44(0.08)$ \\
\hline
\end{tabular}

\# Heterogeneities of two-locus segregations among clones are computed with the expected numbers for each class based on the observed overall segregations, not on the theoretical 1:1:1:1 segregation.

$¥ \mathrm{df}=$ degrees of freedom.

$\S \mathrm{Se}=$ Standart error.

(1990) also indicated that overrepresentation of uncommon alleles may explain the maintenance of these alleles in populations. It appears that such overrepresentations may be due to differential selection of the respective alleles (STRAuss and CONKLE, 1986).

\section{Linkage Analysis}

Eight loci were polymorphic, hence available to study linkage. Of the 28 possible paired combinations of loci, 23 pairs were studied in at least one clone (Table 4). Significant segregation distortion at only one locus of a pair was observed at six pairs (Adh2-Pgi2, Mdh1-Sdh1, Mnr2-Pgd3, Mnr2-Pgi2, Pgd2-Pgd3 and Pgd3-Sdh1). However, no significant segregation distortions at both loci of a pair were observed. Distortion at one locus does not disturb linkage estimates (RUDIN and EKBERG, 1978; Strauss and ConKLe, 1986).

Two-locus segregations in three pairs (Got2-Mdh1, Got2-Pgi2 and Pgd3-Sdh1) were significantly heterogeneous $(\mathrm{P} \leq 0.05)$ (Table 4). These two-locus heterogeneities were due to heterogeneity in segregation ratios at any one of the two loci, not due to heterogeneity of joint segregations. Heterogeneity can be due to significant differences at deficiencies or excesses of various allozymes among the clones, although some clones segregate according to the expected ratios. The data for the Got2-Mdh1 locus pair, for example, have been obtained from six clones; and mainly clones 8 and 27 caused the heterogeneity. This heterogeneity can be due to sampling error or differential viability of gametes carrying different alleles of an allozyme locus (SzMIDT and Muona, 1989; Cheliak and Pitel, 1985). Also, if a locus is linked to a lethal allele of another locus, one can expect deviation from the 1:1:1:1 ratio (SzMIDT and MUONA, 1989; CHELIAK and PITEL, 1984). In some clones given to heterogeneity, deficiencies or excesses of certain alleles can be stable for that clone. This case indicates that the allozyme gene itself, or at least a small part of the chromosome containing that gene, is the target of selection (ADAMS and JoLY, 1980).

Linkage was only accepted if joint segregation was significant at the $\mathrm{P} \leq 0.05$ level and no more than one of the segregating loci showed a deviation from the 1:1 ratio at this $(\mathrm{P} \leq 0.05)$ level. Such a significant joint segregation $(\mathrm{P} \leq 0.05)$ was detected at only two out of 23 locus pairs tested: Adh2-Got2 and Pgi2-Sdh1 (Table 4). The data for linkage study at the Adh2-Got2 locus pair is from only a single clone, for the other locus pair from seven clones (Table 5). Furthermore, the estimated recombination fractions of Adh2-Got2 and Pgi2-Sdh1 were $0.24\left(\mathrm{~S}_{\mathrm{r}}=0.06\right)$ and $0.44\left(\mathrm{~S}_{\mathrm{r}}=0.08\right)$, respectively. Table 5, where the data are evaluated separately for each clones at Pgi2-Sdh1 locus pair, show that there is no significant linkage between Pgi2 and Sdh1 loci, although there appears to be significant joint segregation between these loci when the data are pooled. The estimated recombination fraction values also suggest that there is a weak linkage for only Adh2-Got2 locus pair. Although there is not enough evidence about linkage between the Adh2-Got2 locus pair in previous studies for most of the Pinus species, SzMidT and Muona (1989) and Niebling et al. (1987) mapped Got2 and Adh2 loci into the same linkage group in Pinus sylvestris. 
Table 5. - Two-locus segregation patterns of seven clones for Pgi2-Sdh1 locus pair.

\begin{tabular}{|c|c|c|c|c|c|c|c|c|c|c|c|}
\hline \multirow{2}{*}{$\begin{array}{l}\text { Locus pair } \\
\text { Locus1- } \\
\text { Locus2 } \\
\end{array}$} & \multirow[t]{2}{*}{$\begin{array}{c}\text { Clone } \\
\text { No }\end{array}$} & \multicolumn{4}{|c|}{$\begin{array}{c}\text { Allelic } \\
\text { combination }\end{array}$} & \multicolumn{2}{|c|}{$\begin{array}{c}\text { Segregation } \\
\text { at locus } 1\end{array}$} & \multicolumn{2}{|c|}{$\begin{array}{c}\text { Segregation } \\
\text { at locus } 2\end{array}$} & \multicolumn{2}{|c|}{$\begin{array}{c}\text { Joint } \\
\text { segregation }\end{array}$} \\
\hline & & 11 & 12 & 21 & 22 & $\begin{array}{c}\chi^{2} \\
(d f=1)^{*}\end{array}$ & $\mathbf{P}$ & $\begin{array}{c}\chi^{2} \\
(\mathrm{df}=1)^{*}\end{array}$ & $\mathbf{P}$ & $\begin{array}{c}\chi^{2} \\
(d f=1)^{*}\end{array}$ & $\mathbf{P}$ \\
\hline \multirow[t]{8}{*}{ Pgi2-Sdh1 } & 5 & 7 & 11 & 14 & 9 & 0.61 & 0.43 & 0.02 & 0.88 & 1.98 & 0.16 \\
\hline & 11 & 16 & 15 & 6 & 8 & 6.42 & 0.01 & 0.02 & 0.88 & 0.20 & 0.65 \\
\hline & 14 & 6 & 5 & 10 & 5 & 0.62 & 0.43 & 1.38 & 0.24 & 0.62 & 0.43 \\
\hline & 17 & 7 & 11 & 9 & 11 & 0.11 & 0.75 & 0.95 & 0.33 & 0.11 & 0.75 \\
\hline & 19 & 10 & 11 & 15 & 6 & 0.00 & 1.00 & 1.52 & 0.22 & 2.38 & 0.12 \\
\hline & 24 & 10 & 13 & 18 & 8 & 0.18 & 0.67 & 1.00 & 0.32 & 3.45 & 0.06 \\
\hline & 28 & 6 & 7 & 9 & 10 & 1.13 & 0.29 & 0.13 & 0.72 & 0.00 & 1.00 \\
\hline & Pooled & 62 & 73 & 81 & 57 & 0.03 & 0.85 & 0.62 & 0.43 & 4.5 & 0.03 \\
\hline
\end{tabular}

$* \mathrm{df}=$ degrees of freedom

\section{Conclusion}

The segregation of allozymes in megagametophytes of heterozygous individuals reveals that seven out of the eight polymorphic loci studied did not deviate significantly from the Mendelian independent segregation rule.

The results obtained from linkage analysis showed that one of the 23 locus-pairs (Adh2-Got2) was weakly linked and that two-locus segregations in three pairs (Got2-Mdh1, Got2-Pgi2 and Pgd3-Sdh1) were significantly heterogeneous. In many population genetic analyses of forest trees (for example mating system parameters) an assumption of independence is required, and unlinked loci provide more efficient and more accurate estimates for obtaining certain parameters (SHAW et al., 1981). Loci that are linked are clearly not independent and, therefore, should not be used for such estimates. In case of linked loci, one locus of the related pair must be discarded. Because there is no other evidence of linkage for the Adh2-Got2 locus pair in Pinus species, the weak linkage observed in this study needs to be verified by increasing sample size, before taking into account each of these two loci for various population genetic analyses.

\section{Acknowledgement}

This study was supported by Akdeniz University Scientific Research Projects Unit (Project No: 99.01.0105.04). TUBITAK-BAYG/BDP program granted a seven months research scholarship to NURAY KAYA to study at Oregon State University (OSU), Corvallis, ORE, USA. Dr. W. T. AdAms (OSU) and Dr. VAlERIE HiPKINS (Pacific Southwest Research Station, National Forest Genetics Laboratory, CA, USA) provided valuable comments during the analysis and interpretation of the data. YUSUF CENGIZ (Southwest Anatolia Forest Research Institute, Antalya) provided logistic support during the seed sampling in the seed orchard. Dr. V. HiPKINS also reviewed the initial version of the manuscript. We gratefully acknowledge the contributions of all these persons and institutions.

\section{References}

ADAms, W. T. and R. J. JoLY (1980): Linkage relationships among twelve enzyme loci in loblolly pine. The Journal of Heredity 71: 199-202.
Adams, W. T., D. B. Neale, A. H. Doerksen and D. B. SMITH (1990): Inheritance and linkage of isozyme variants from seed and vegetative bud tissues in coastal Douglas-fir [Pseudotsuga menziesii var. menziesii (Mirb.) Franco]. Silvae Genetica 39: 153-167.

Boyle, T. J. and E. K. Morgenstern (1985): Inheritance and linkage relationships of some isozymes of black spruce in New Brunswick. Can. J. For. Res. 15: 992-996.

Brown, A. H. D., A. C. Matheson and K. G. Eldridge (1975): Estimation of the mating system of Eucalyptus obliqua L'Herit. by using allozyme polymorphisms. Aust. J. Bot. 28: 931-949.

Cheliak, W. M., K. Morgan, B. P. Dancik, C. Strobeck and F. C. H. YEH (1984): Segregation of allozymes in megagametophytes of viable seed from a natural population of jack pine, Pinus banksiana Lamb. Theor. Appl. Genet. 69: 145-151.

CheliaK, W. M. and J. A. Pitel (1985): Inheritance and linkage of allozymes in Larix laricina. Silvae Genetica 34: 142-148.

FAROOQ, S. and F. AzAM (2002). Molecular markers in plant breeding-II. Some prerequsities for use. Pakistan J. of Biol. Sci. 5(10): 1141-1147.

Furnier, G. R., P. Knowles, M. A. Aleksiuk and B. P. DANCIK (1986): Inheritance and linkage of allozymes in seed tissue of white bark pine. Can. J. Genet. Cytol. 28: 601-604.

Geburek, T. and G. von Wuehlisch (1989): Linkage analysis of isozyme gene loci in Picea abies (L.) Karst. Heredity 62: 185-191.

KarA, N., L. Korol, K. IsIK and G. Schiller (1997): Genetic Diversity in Pinus brutia Ten.: Altitudinal variation. Silvae Genetica 46 (2-3): 155-161.

KaYA, N. (2001): Estimation of Mating System and Pollen Contamination in a Clonal Seed Orchard of Pinus brutia Ten. in Asar-Antalya. Ph. D. Thesis, Akdeniz Univ., Graduate School of Natural and Applied Sciences, 81 pp. (in Turkish with English summary).

KAYA, N., K. IsIK and W. T. ADAMs (2005): Mating system and pollen contamination in a Pinus brutia seed orchard. New Forest 00:1-8. DOI 10.1007/s11056-0050876-x

NeAle, D. B. and W. T. AdAms (1981): Inheritance of isozyme variants in seed tissues of balsam fir (Abies balsamea). Can. J. Bot. 59: 1285-1291.

Niebling, C. R., K. Johnson and H. D. Gerhold (1987): Electrophoretic analysis of genetic linkage in Scots pine (Pinus sylvestris L.). Biochemical Genetics 25 (11-12): 803-814. 
Rudin, D. and I. EKBERG (1978): Linkage studies in Pinus sylvestris L.-using macro gametophyte allozymes. Silvae Genetica 27: 1-12.

SHAW, D. V. and R. W. Allard (1981): Analysis of mating system parameters and population structure in Douglas-fir using single-locus and multi-locus methods, pp. 18-22. In: Proc. Symp. Isozymes North Am. Forest Trees and Forest Insects edited by ConkLE, M. T.,
Berkeley, C. A. USDA Forest Serv. Gen. Techn. Rep. PSW-48.

Strauss, S. H. and M. T. ConkLE (1986): Segregation, linkage and diversity of allozymes in knobcone pine. Theor. Appl. Genet. 72: 483-493.

SzmidT, A. E. and O. MuONA (1989): Linkage relationships of allozyme loci in Pinus sylvestris. Hereditas 111: 91-97.

\title{
Genetic Diversity and Gene Flow of Quercus crispula in a Semi-Fragmented Forest Together With Neighboring Forests
}

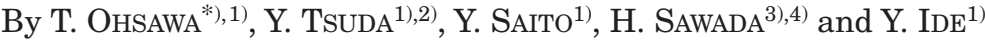

(Received $26^{\text {th }}$ October 2005)

\begin{abstract}
The genetic diversity and differentiation in Quercus crispula populations in the Chichibu Mountains, central Japan, were evaluated using six microsatellite markers. Gene flow into a $2500-\mathrm{m}^{2}$ semi-fragment of a natural forest from the neighboring natural forest at a distance of more than $50 \mathrm{~m}$ was also evaluated using parentage analysis. All five populations in the mountains had similar levels of genetic diversity $\left(H_{\mathrm{e}}=0.752-0.792\right)$, and the level of population differentiation was low $\left(F_{\mathrm{ST}}=0.016\right)$. The semi-fragmented stand showed similar genetic diversity with the neighboring unfragmented forests, and Hardy-Weinberg disequilibrium was not found $\left(F_{\text {IS }}=0.083\right.$ in adults, 0.025 in seedlings $)$. In the semifragment, 70 seedlings were examined; according to the parentage analysis, eight of the 70 seedlings (ca. 11\%) had neither of the parent trees in this fragment. These seeds must have been transported from a distance of more than $50 \mathrm{~m}$; therefore, there could be a possibility that the seeds were dispersed by birds. A similar trend of seed flow into the fragment was also confirmed by genotyping endocarps of hypogeal cotyledons, while more frequent seed flow was found in the neighboring unfragmented forest. Of the remaining 62 seedlings, the maternal trees (but not the paternal trees) of 29
\end{abstract}

1) Department of Ecosystem Studies, Graduate School of Agricultural and Life Sciences, the University of Tokyo, Yayoi 1-1-1, Bunkyo-ku, Tokyo 113-8657, Japan.

2) Forest and Forest Production Research Insitute, Matsunosato 1, Tsukuba-shi, Ibaraki 305-8687, Japan.

3) University Forest in Chichibu, Graduate School of Agricultural and Life Sciences, the University of Tokyo, Hinoda 1-1-49, Chichibu-shi, Saitama 368-0034, Japan.

4) University Forest in Aichi, Graduate School of Agricultural and Life Sciences, the University of Tokyo, Goizuka 11-44, Seto-shi, Aichi 489-0031, Japan.

*) Communicating author: TAKAFUmi OHSAWA, Department of Ecosystem Studies, Graduate School of Agricultural and Life Sciences, the University of Tokyo, Yayoi 1-1-1, Bunkyo-ku, Tokyo, Japan. Phone: +81-03-5841-8208. Email: aa56258@mail. ecc.u-tokyo.ac.jp seedlings and both parent trees of 33 seedlings were detected in the semi-fragment. These results indicate that the gene flow among the populations occurs frequently via pollen dispersal and occasionally via seed dispersal and that, at least the current levels of genetic diversity have been maintained in such fragmented forests.

Key words: forest fragmentation, microsatellites, parentage analysis, Quercus crispula.

\section{Introduction}

Since many years, forest fragmentation has resulted from human activities and has been affecting many ecosystems worldwide, including Japan. A geographic information system (GIS) analysis revealed that $53 \%$ of forest patches were smaller than 1ha even in rural area (MiYAmoto and SHIMAdA, 2001). In this country, semifragmented natural stands located close to neighboring natural stands are found more frequently rather than those far away from other natural stands. This is partly due to the construction of roads and buildings in the natural forests as seen in other countries. Many trunk roads with a width of several ten meters run through the natural forests. In addition, many mountains are occupied by various small stands due to cutting or planting activities of private small-scale forest owners (KONOHIRA, 1996). Approximately $41 \%$ of all forests in Japan are man-made (ANON, 1994), and this percentage is much higher than that in other countries. The unique geographical feature of Japan is one of the reasons for the large number of semi-fragmented natural stands. Of the total Japanese land area, 75\% is classified as mountainous or hilly, and $60 \%$ of the forest area is characterized as having a slope of $20^{\circ}$ or more (HANDA, 1988). Many areas consist of very steep rocky slopes. Consequently, natural stands are often found on partially steep slopes; these are inappropriate for afforestation. Therefore, these semi-fragments are at short distances 